Proc. Estonian Acad. Sci. Biol. Ecol., 2004, 53, 3, 208-225

\title{
The effect of man-caused disturbances on the development dynamics of forest communities on Abruka Island (West Estonia)
}

\author{
Toivo Meikar ${ }^{\mathrm{a} *}$, Kaili Viilma ${ }^{\mathrm{b}}$, and Alar Lepp ${ }^{\mathrm{c}}$ \\ ${ }^{a}$ Forest Research Institute, Estonian Agricultural University, Kreutzwaldi 5, 51014 Tartu, Estonia \\ ${ }^{\mathrm{b}}$ Foundation for Forest Conservation, Rõõmu tee 2, 51013 Tartu, Estonia \\ ${ }^{\mathrm{c}}$ Faculty of Forestry, Estonian Agricultural University, Kreutzwaldi 5, 51014 Tartu, Estonia
}

Received 7 November 2003

\begin{abstract}
Today's Abruka Island (West Estonia) hosts a species-rich and lush nemoral forest, which has been regarded as a relict of broadleaf forests once widespread in Estonia that survived thanks to the local mild maritime climate. Written sources until the mid-19th century, however, describe Abruka as a habitat of spruce forests. Spruce-dominated stands were prevalent on the island until at least the 1860s. The 1898 forest survey registered a shift in the dominant tree species to the birch - at that time birch stands constituted up to $84 \%$ of the island's total forest area. In fact, the decisive determinant of forest communities of Abruka Island over the last couple of centuries has been man, who since the early 19th century has clear cut without reforestation or maintenance felling. By the 1930s, when a protection regime was enforced on the island, the percentage of spruce dominated stands had dropped to $0.1 \%$ and the overall share of the spruce had shrunk to $8.4 \%$. The enforcement of the protection regime has led to an increse in the forest species diversity and created conditions for restoring the share of the spruce as a tree species well suited to the island's soil conditions.
\end{abstract}

Key words: historical forest data, communities development, management plan, broadleaf, mancaused disturbances.

\section{INTRODUCTION}

Considerable slow natural processes also include many occasional occurrences - natural disturbances, that is, events significantly and rapidly affecting forest age and structure, such as windstorms, floods, and forest fires. At the same time, the intensity and extent of such disturbances may largely be determined by human activity, such as reducing the wind resistance of stands by inappropriate logging

\footnotetext{
* Corresponding author, meikar@eau.ee
} 
methods, creating pure stands, destroying natural water regime, etc. Nowadays the most extensive forest disturbances are man-caused, related to forest management, i.e. to reforestation, systematic maintenance, and controlled logging. Silvicultural actions compared to natural disturbances are usually more frequent and intentionally or unintentionally aimed at simplifying the natural structure of forest. This typically results in the formation in commercial forests of stands composed of same-age and homogeneous trees while less intensive forest utilization leaves plenty of processes in nature's care (Jõgiste et al., 2002).

Estonia's forest communities are overwhelmingly secondary in origin. Their composition, way of formation, and site conditions have been influenced to a lesser or greater extent by man's economic activities. Although forests apparently untouched by human activity (old-growth forests) can be found here in scattered stands on up to 500 hectares, Estonia has slightly more forests that have grown naturally and left alone by man for at least one forest generation, so-called natural forests. In addition, so-called recovering forests occur in regions where economic activity is lower or restricted for some reason (such as conservation) and in strict nature reserves (Jõgiste et al., 2002). Quite often the origins of forest communities now assumed as natural may be traced back to man-caused disturbances. An illustration of this may be the nemoral deciduous forest on Abruka Island. For some time already, a number of studies have been written to expound the species and interrelationships found in that allegedly old-growth forest community, without viewing the forest's development from a longer, historical perspective.

The forest on Abruka Island has traditionally been regarded as a unique relict of broadleaf forests once widespread in Estonia. Accordingly, the island's forests should date from approximately 3800-2700 BC, when the expansion of broadleaf forests in the Late Atlantic Era reached its peak on Estonia's territory (Laasimer, 1965). At the same time, researchers have questioned the lack of spruce-deciduous communities, which would have been expected to occur here considering the soil conditions of at least the central part of the island. They have attributed it to the unfavourable growth conditions for the spruce under the shady broadleaf forest or to frequent windstorms not allowing the spruce to compete with deciduous trees. Researchers also point to the fact that the local forest lands have never been used for temporary agriculture, which, combined with the maritime climate, has ensured reforestation in the more or less original form. It has also been assumed that the lower moisture content of the soils in the island's centre is to blame for suppression of the spruce by deciduous trees (Lippmaa, 1937, 1939, 1940; Laasimer, 1958; Kalda, 1979).

More intensive scientific research on Abruka Island started in the mid-19th century, when a number of Tartu University students and secondary school teachers worked there. In 1852 the island was visited by Tartu University Botany Professor Alexander Georg von Bunge, accompanied by Friedrich Schmidt, then a student and later a professor, who as a result of the several-years' fieldwork published important systematic studies on the flora and geology of the island of Saaremaa (Sass, 1867). Neither he nor the other nature scientists of his day placed any 
particular emphasis on Abruka; at best, they viewed it as one, and not the most important, part of the botanically interesting regions of Saaremaa Island. While Schmidt mentions, without any detail, the lush forest of Abruka, his attention is much more attracted by the elm-ash-black alder community growing on the inner slopes of the Kaali meteorite crater (Schmidt, 1855).

It is not until late that century that publications advertizing Saaremaa start to include Abruka Island as a prospective tourist destination for its beautiful and lush forests, in which a striking stand of mature spruce is again and again noticed apart from those of several broadleaf species (Meikar, 1992). By the turn of the century, however, some developments had taken place in Abruka forests that in line with the spread of conservationist ideas even raised the question of placing the island's forests under governmental protection before World War I.

A new stage in the scientific research of Abruka was reached in the days of the Republic of Estonia. Abruka forests won international attention thanks primarily to Prof. Teodor Lippmaa's geo-botanical studies, for which the island's species richness as well as its forest community, unique in Estonia's circumstances, became one of the key experiment grounds in the development and substantiation of the synusiae method (Lippmaa, 1935). Lippmaa possessed consistent information on the logging operations, including clear cutting, performed on the island in the last 40 years, which enabled him to analyse, among other things, regeneration processes of cutting areas in different forest communities. Yet it was not found that by the late 19th century the island's previous forest community had already experienced substantial changes.

The history of forest management on Abruka was traced even further back by forest scientist Bernhard Tuiskvere (1938), who proved on the basis of archival data that systematic clear cutting had been employed on the island as early as in 1848. Although the archival source he used also contains important information about the forests' species composition, this did not attract the attention of either that author or later researchers. Similarly, they did not realize the relationships between the long-term clear cuttings and the potential changes in the development of the island's forests. That the clear cuttings employed since the early 19th century have substantially shaped the forest community of today's Abruka was discovered after perusal of the archival records dealing with previous management of the island's forests (Meikar, 1992; Meikar et al., 1999).

This paper examines the changes in the forest community of Abruka Island observed over the last couple of centuries, which have been seen as resulting from disturbances predominantly related to human activity. In the period covered by written records (350 years), the number of natural disturbances on Abruka has been relatively small. The most significant of those was the extensive withering of the island's spruce forests in the early 1740s, which later has been attributed to an epidemic of nun moth (Lymantria monacha) and subsequently of spruce bark beetle (Ips typographus) (Voolma, 1998). Since the late 19th century there have been reports of root rot outbreaks in spruce forests. Another natural disturbance to more significantly affect the stand communities was the 1969 autumn windstorm. 


\section{MATERIALS AND METHODS}

Abruka Island, situated approximately $6 \mathrm{~km}$ south of Saaremaa Island, hosts on its total area of 878 hectares a more than 300-ha forest. The latter predominantly represents a moist-to-paludifying nemoral forest of trees of different ages and number of species, and of multiple storeys, including a lush grass storey. Apart from the dominant dwarf birches (Betula pubescens) the forest accommodates spruces (Picea abies), ashes (Fraxinus excelsior), black alders (Alnus glutinosa), aspens (Populus tremula), and other deciduous trees. In some places typical swamp forest can be found. In the southern part of the island the forest changes to oak (Quercus robur) woodland overgrown with bushes. Unique in Estonia, an elmmaple-lime (Ulmus glabra-Acer platanoides-Tilia cordata) community resembling the beech forests of Central Europe has spread over approximately 5 ha in the northwestern part of the island (Kalda, 1979).

The clearly recognizable borders in time (sea coast), source materials dating from distant past, and numerous scientific studies make the forest on Abruka Island a fairly exceptional object of research. The island's forest area has fluctuated between only 310 and 350 ha over the last 200 years. As such, the development of Abruka forest can be regarded as a dynamic process occurring under identical climatic and soil conditions.

The analysis of the development of the island's stands and of the share of man-caused disturbances in the changes observed is based on the forest surveys performed on the island and on other archival records, which constitute a more or less continual set of data beginning from the late 18th century. The following archive and digital materials were analysed and processed for the current study: description of Abruka Island with the first detailed description of forest communities from 1790; first simplified forest survey from 1809; forest description from 1837; forest description from 1860; forest description from 1870; forest map from 1896; the first full forest survey data with a map from 1898; full forest survey data with a map from 1924; application and explanation for establishment of protected area; full forest survey data with a map from 1949; full forest survey data with a map from 1957; full forest survey data with a map from 1967; full forest survey data with a map from 1978; full forest survey data with a map from 1986, and full forest survey data with a map from 1996. Materials of all full forest surveys were structured, digitized (including forest maps), and used for forest growth analysis. Stand descriptions of the last two forest surveys (from 1986 and 1996) were already available in digital form and only the forest map from 1986 was digitized. Additional field measurements were carried out in 1998-1999 in Abruka Island to check errors in the last forest survey data and evaluate the stands' naturalness and health and the impact of management methods on stand development. All forest subcompartments were inventoried and additional measurements were carried out in the case differences from the last forest survey data were observed. Species experts registered remarkable (protected, rare, and indicator) species of different species groups, but results of their work were used only as an argument to prove the high nature value of the island's forests. 
Considering the fact that the first full forest survey on the island was conducted in 1898, the 18th-19th century forest maps and descriptions (in essence, simplified management schemes) are particularly significant with regard to the theme under study, since it was at that particular period that the formation of today's forest community was largely determined. It is not possible, however, to achieve oneto-one compatibility of all that material with the respective data from the later forest surveys (in 1898, 1924, 1949, 1957, 1967, 1978, 1986, 1996) that are considerably more informative. Accordingly, it is only from the 1898 survey that the data at the stand subcompartment level can be adequately related to those obtained from the later more sophisticated surveys.

The earlier forest descriptions and surveys emphasized the distinguishing of the main tree species, determining the management regime. In terms of Abruka this meant that the spruce was registered as the dominant and co-dominant coniferous species while normally only the birch, the black alder, and the aspen were registered of the deciduous trees. The actual species richness of the Abruka forest and the accuracy of the changes recorded was established only after analysis of the postWWII forest surveys, thanks to the decrease in the area of stand subcompartments and the more precise registering of the co-dominant tree species in the stands. The shares of the tree species were calculated by multiplying the share of the first layer species in a subcompartment by the area of the subcompartment, then adding up the results by tree species and dividing the totals by the area of the forested woodland.

In order to link the data obtained from the past forest surveys performed on a particular site (in the case of Abruka, the data from eight forest surveys) and make them processable by modern technological means, the data from the different forest surveys were first structured on unified principles. In the structures, the following was indicated:

- year of survey;

- materials available (survey descriptions, maps, spatial arrangements, etc.);

- data levels (survey, compartment, subcompartment, layer, and tree species);

- registered forest characteristics and stand parameters (ground cover, soil, water regime, site index, height, diameter, cuttings, etc.);

- units of measure (foot, cord, cubic foot, inch, metre, etc.);

- type of comments (work done, success of cutting, results of reforestation, etc.).

Based on the structured data, special software geared to the modern forest management methods was developed for Visual FoxPro environment. The software was to enable the entering of all the available data, thus it was developed on the basis of modern survey databases as the most detailed ones, and then supplemented with the entry fields required for digitizing the historical data. Each database included the so-called custom fields, which could be named if necessary and used for entering the respective parameter data (for instance, compartment lines, other lands, etc.). A description could be included as free text on the "Memo" field to describe the forest surveys and explain the entry interpretation methods. 
The software enables to summarize the key forest survey parameters by converting the source data entered in original units of measure into SI units while preserving their original values. This permits further analysis, checking, and comparison of the data.

The structured survey data from all the surveys were entered into the respective application. Then checks were run for eliminating errors from the data entered. Upon encountering an entering error, the data were corrected and, in the event of incomplete forest survey data, were completed as required by the program. From the corrected and completed databases, summaries were composed by surveys for the following parameters: the forested area of the object of research, the stand growing stock, the average stand density, the share of tree species (stand composition), the average height (H100), diameter (D200), and growing stock (M100) by tree species at the age of 100 years, as well as the average age and density by tree species. The survey data were related to the digitized map data, which enables to link the data with coordinates and lends itself to the investigation of the dynamics of the forest communities and of the effect in time of the management techniques applied as determined from a point-based time series.

\section{THE DYNAMICS OF ABRUKA STANDS}

The first specific records concerning the Abruka forest date back to 1650 when it, a so-called manor forest (der Schlossbusch zu Abrö), was considered one of the best in the Saaremaa region. At that time mature spruce trees were growing there to make a so-called high forest. A beautiful spruce forest growing on the island was also pointed out a century later, apart from the secondary species of ash, lime, and maple. Considering the site conditions, the spruce may be regarded as one of the most vital tree species here, and its dominance in the naturally grown forest is something to be expected. A more detailed overview of the Abruka forest was first provided in the island's map description of 1790. According to the description of the total 323 ha forest, large spruces were dominating, seconded by birches, black alders, aspens, maples, and, to some extent, crab apples (Malus sylvestris). In addition to the forest, the island hosted approximately 46 ha of forest-like hayfields, pasturelands, and wastelands covered with the above-listed tree species (Meikar et al., 1999). Accordingly, the 18th-century data suggest that the Abruka forest represented a rich-in-species spruce-hardwood mix. The dominant tree was the spruce, which was regarded as the only species of economic importance. To some extent, the forest must have contained oaks, which, however, were more common on the island's hayfields and pasturelands. Apparently, it was precisely the former oak mixes that developed into the species-rich sprucehardwood mix, which today could rather be classified as a meso-eutrophic forest than a nemoral forest.

According to the 1835 forest description data, Abruka held a 328-ha sprucedominated mixed forest. In the western part of the island, the age of the main tree 
species was predominantly $40-80$ years while in the eastern part, which at that time was already affected by clear cuttings, it was not more than 40 years. Of other tree species, the birch and the aspen are mentioned. These two were also registred a few years later, then for the first time as species of economic importance along with the black alder. Additionally, the forest must have included broadleaf tree species, even though they were not registered in the forest descriptions. The hayfields on the island's west coast were also forest-like. According to the 1848 data, the forest was dominated by mature stands, of which $58 \%$ were categorized as spruce stands and the rest as birch stands, aspen stands, and spruce-hardwood mixes. The 1869 description put the proportion of spruce stands at $70 \%$, of birch stands at $20 \%$, and of black alder stands at $10 \%$ (Table 1). By virtue of the sprucehardwood mixes, however, the share of deciduous trees should be considered higher. The forest itself exhibited a tendency towards rejuvenation. Its overall condition was rated as good, in some places even very good, which is surprising in view of the fact that the island's best spruce stands had been felled in the previous ten years (Meikar et al., 1999).

According to the first full forest survey of 1898 , the island had 317 ha of woodland, of which 291 ha was stands. Yet the forest's species composition had experienced a drastic change $-84 \%$ of the total area was now under birch stands, $5 \%$ under black alder stands, and barely $11 \%$ under spruce stands. In fact, the Abruka forest had still maintained the appearance of a mixed forest. Pure birch stands were nowhere to be found while the spruce maintained a presence almost everywhere as a co-dominant species, usually accounting for 10-40\% in birch stands. In spruce-dominated stands, the share of spruce was up to $60 \%$. The spruce, mixed with deciduous species, was also represented among the young stands on cutting areas. The share of the aspen in subcompartments occasionally reached $40 \%$. In addition, the elm, the maple, the white willow (Salix alba), the ash, other willow species (Salix spp.) and, in the shrub layer and open stands, the

Table 1. Dominant tree species in stands on Abruka Island in 1848-1996 (\%)

\begin{tabular}{c|c|c|c|c|c|c|c|c|c|c|c}
\hline Year & Spruce & Birch & $\begin{array}{c}\text { Black } \\
\text { alder }\end{array}$ & Aspen & Lime & Pine & Ash & Elm & Maple & Juniper & Hazel \\
\hline 1869 & 70.0 & 20.0 & 10.0 & - & - & - & - & - & - & - & - \\
1898 & 10.4 & 84.3 & 5.3 & - & - & - & - & - & - & - & - \\
1924 & 0.1 & 99.9 & - & - & - & - & - & - & - & - & - \\
1949 & - & 96.9 & - & 1.3 & - & 1.8 & - & - & - & - & - \\
1957 & - & 95.1 & - & 0.7 & 2.5 & 1.7 & - & - & - & - & - \\
1967 & 2.6 & 91.0 & - & 1.5 & 1.5 & 1.2 & 1.5 & 0.7 & - & - & - \\
1978 & - & 83.0 & - & 2.1 & 1.4 & 1.0 & 0.2 & - & - & 4.8 & 7.5 \\
1986 & - & 83.4 & - & 2.1 & 3.2 & 1.0 & 4.6 & - & 0.7 & 4.7 & 0.3 \\
1996 & - & 84.2 & - & 3.1 & 3.7 & 1.6 & 3.4 & 0.6 & 1.7 & 1.2 & 0.5 \\
\\
\hline
\end{tabular}


hazel (Corylus avellana) were registered as sole trees or tree groups. In very rare instances, the grey alder (Alnus incana) was spotted on higher places. Oaks suitable for shipbuilding could be found in hayfields. Notable for its species richness was the northwestern part of the forest (the later wildlife reserve compartment), less so the southeastern part.

According to the 1924 forest survey, Abruka had 320 ha of forest land, with the stand area having dropped to 256 ha. The birch was dominating everywhere while the share of spruce stands had shrunk to approximately $0.1 \%$ of all the stands. Even so, it must be taken into account that the forest was considerably richer in species than the statistics show. While the birch enjoyed absolute dominance in the island's southeastern part, it accounted for $60-70 \%$ in the stands elsewhere, accompanied by the spruce, the black alder, the aspen, and other unspecified deciduous species. Also registered were the lime (Tilia cordata), the elm, and the oak, primarily in open stands. Even ten years later, in an overview article of the island of Saaremaa, the Abruka forest was considered one of the species-richest nemoral forests in the county, in which the dominant birch was considerably complemented by the aspen, the elm, and the lime, less so by the spruce, the rowan, the maple, and the ash and, on higher places, by an occasional oak (Eichwald, 1934).

A new forest survey on Abruka was performed in 1949. It put the size of the local forestland at 317 ha, including 310 ha of stands. In 1937 part of the island was taken under protection and cutting ban was applied. Judging by the dominant tree species, birch stands had overrun the island (97\%). Apart from them, aspen stands and, as plantations from an earlier period, even pine stands were registered. Yet in some places (on approximately $90 \mathrm{ha}$ ) the second stand layer was composed exceptionally from the spruce. Especially in the northwestern part of the island numerous secondary species (besides the above-mentioned, the lime, the oak, the ash, the elm, the maple, the black alder, etc.) were registered. When comparing the earlier forest surveys and the one of 1949 , however, it must definitely be taken into account that the latter was much more accurate. Because of that, compatibility is best between the forest survey data of the post-WWII period.

Based on dominant tree species, Table 1 presents data from nine forest descriptions and surveys spanning over approximately 130 years to reflect the changes observed in Abruka stands. The data convincingly demonstrate the extent of the changes observed. In their time, the data were suitable for planning forest management operations yet they are not truly representative of the species composition and the dynamics of the forest. Therefore, it is practical to disregard the dominant tree species when considering the later more advanced forest surveys and to analyse the entire species diversity of the forest using the opportunity given by the forest survey data.

A comparison of the spread of the dominant and co-dominant tree species measured in 1898 and 1924 reveals further vigorous expansion of the birch, primarily at the expense of the spruce and the aspen (Table 2). At the same time, the data confirm a species richness which is already representative of a nemoral 
Table 2. Share of tree species of Abruka forests in 1869-1996 (\%)

\begin{tabular}{l|c|c|c|c|r|c|c|c|c|c|c|c|c}
\hline Year & Birch & Aspen & $\begin{array}{c}\text { Black } \\
\text { alder }\end{array}$ & Ash & Spruce & Elm & Oak & Lime & Pine & Maple & Juniper & Willow & Hazel \\
\hline 1898 & 43.7 & 12.8 & 19.4 & - & 24.0 & - & - & 0.1 & - & - & - & - & - \\
1924 & 82.4 & 6.1 & 3.1 & - & 8.4 & - & - & - & - & - & - & - & - \\
1949 & 67.1 & 9.0 & 6.1 & 3.0 & 9.5 & 1.2 & 0.6 & 0.5 & 1.4 & 0.1 & 1.5 & - & - \\
1957 & 70.4 & 9.0 & 6.2 & 2.6 & 7.2 & 0.7 & 1.0 & 1.5 & 1.4 & - & - & - & - \\
1967 & 57.6 & 6.7 & 5.7 & 6.5 & 16.2 & 1.3 & 3.2 & 1.8 & 0.8 & 0.1 & - & 0.1 & - \\
1978 & 62.5 & 8.8 & 4.5 & 6.3 & 3.3 & 0.3 & 1.6 & 0.9 & 0.5 & 0.2 & 4.3 & - & 6.8 \\
1986 & 57.8 & 8.2 & 5.3 & 10.4 & 5.3 & 3.7 & 4.0 & 0.5 & 1.1 & 1.3 & 2.4 & - & - \\
1996 & 52.2 & 8.2 & 6.7 & 10.7 & 6.7 & 4.5 & 4.8 & 2.0 & 1.1 & 3.1 & - & - & - \\
\hline
\end{tabular}

- not registered.

forest. In 1898, apart from the above-mentioned species, the elm, the maple, the white willow as well as, in the shrub layer and in open stands, the hazel were registered as single trees or groups of trees; in 1924, primarily in sparse stands, the lime, the elm, and the oak.

With regard to the dominant and the secondary tree species the 1949 forest survey put the share of the birch as a total for all stands at $67.1 \%$ (Table 2). The proportions of the aspen $(9.0 \%)$ and the black alder $(6.1 \%)$ were also relatively high. The share of other deciduous trees remained below 3\%, totalling up at 5.4\%. The proportion of the spruce was evaluated at up to $10 \%$.

The 1957 forest survey registered a rise in the share of the birch, the lime, the oak, and some other species (Table 2). Ten years later (1967), the dominant tree was still the birch, yet the spruce had reached the first stand layer (Table 1). An analysis of the percentage of stand tree species revealed a substantial decrease in the share of the birch against the considerable gains made by the spruce and the ash (Table 2).

In 1969, the forest of Abruka was destroyed by a fierce windstorm. Of the tree species, the greatest damage was done to the spruce and the elm, which according to the 1978 forest survey no longer existed as stands. For the first time, mention as separate stands was made of the juniper and the hazel, yet the reason for that was the temporary inclusion in forested lands of lands overgrown with bushes (Table 1). Major changes were observed in the old limes, elms, birches, aspens, and some solitary spruces growing primarily in the sparse nemoral forest located at the central ridge of the island. An analysis of the tree species again revealed gains in the proportion of the pioneer species, the spruce and the aspen. After the windstorm, the better light and nutritional conditions in the damaged forest favoured the flourishing of the hazel. Eventually, the former forest was supplanted by a dense hazel coppice mixed with thornbushes (Crataegus sp.). The proliferation of hazel coppices even raised doubts about the future validity of the claim that Abruka could boast of an elm-maple-lime forest (Kalda, 1979; Table 2). 
An analysis based on the 1986 forest survey (Table 2) indicated a further steep decline in the share of the birch and, to a lesser extent, of the aspen in the stands. Contrariwise, the proportion of the spruce as well as some hardwood deciduous trees, such as the ash, the oak, and the elm, again evidenced a rapid gain. Accordingly, Abruka forests grew even more diverse than earlier.

An analysis based on the 1996 forest survey and the check on the survey data conducted during fieldwork in 1998 generally revealed the same tendency of tree species variation in Abruka forests. The proportion of the birch continues to fall while those of the spruce and most deciduous species go up, and those of the aspen, the ash, and the pine stay roughly even (Table 2 ). That there are plenty of tree species expanding at the expense of the birch must be considered an advantageous development from the perspective of natural diversity. After some time, the spruce can be expected to become a dominant tree species again.

At the moment, it is difficult to predict what the further development of Abruka forests will be like over a longer period, for instance over the next two hundred years, if left alone by man. At least in the post-WWII period the highest growth rate was observed in the ash, whose share has risen by approximately $8 \%$, or 3.6 times, over 50 years. Compared to 1949 , the elm, the oak, the lime, and the maple have also spread. The proportion of the black alder as well as of the pine, which was formerly favoured as a forest plantation, has been relatively stable. The greatest drop in the stand share, in both relative and absolute terms, was shown by the birch (by 15\%), and a somewhat smaller one by the other pioneer species of clearcut areas - the aspen. The rise in the rate of the spruce was interrupted by the 1969 windstorm, yet the developments of the last 50 years allow the assumption that under no human intervention in a more distant future the forests of Abruka Island will again transform into spruce forests. Definitely, the island's forests do not represent a stable forest community, which under a reservation regime would preserve its present look for a longer period of time.

\section{THE ROLE OF HUMAN ACTIVITY IN THE DEVELOPMENT OF THE FOREST COMMUNITIES OF ABRUKA ISLAND \\ The period of moderate human activity (until the early 19th century)}

Permanent human habitation on Abruka Island emerged as late as in the first half of the 18th century. Formerly the local fields were tilled and horses bred by peasants residing on Saaremaa Island. In 1731 there were 31 households on Abruka Island. Earlier the island's saw timber forest had been utilized in the interests of the Kuressaare fortress; since the 18th century, however, conifer logs started to be sent to less wooded state-owned manorial estates on Saaremaa, firewood also to the town of Kuressaare. The islanders' own demand for wood was modest, as was that of the local state-owned manorial estate. There are no reports 
of slash-and-burn agriculture ever being applied on the island. Forest use was confined to moderate selection cuttings, which had no significant effect on the forest community. The thinning out of oaks may be assumed, even though it was regulated by the law. All the 18th-century descriptions of Abruka state-owned manorial estates stress the abundance of timber and firewood and emphasize the local mature spruce forest. The latter was in fact spreading primarily at the island's central ridge whereas the forests growing on lower lands represented the spruce in a mix with a diversity of deciduous species.

\section{The use of clear cuttings and the management of Abruka forests as so-called high forests}

In 1809 the first simplified forest survey was performed on Abruka, under which the local forest was divided by a north-to-south and an east-to-west compartment line (transect) into four felling sections. In the first section used, 20 one-year felling areas of approximately equal size were set apart. An 80-year rotation system typical of spruce management was envisaged. By the late $1820 \mathrm{~s}$ most of the old forest in the island's eastern part had been felled, leaving behind beautiful spruce saplings in a mix with deciduous trees. In 1827 logging was launched in the forest on the island's western side by 4.1-ha areas. By the late 1860 s cuttings had been performed throughout the island's western forest. Except for a 10-year period (1838-1847), one-year felling areas bordering on one another were logged (Fig. 1). During the 10 years, the every-other-area felling method was used in the hope of achieving better natural regeneration; however, the hope proved unsubstantiated and the forest itself became vulnerable to wind. In the 1870s the cuttings were concentrated to the eastern part of the island again. As before, logging by 4.1-ha areas was applied, this time in combination with sanitary cutting all over the forest if necessary.

The intensity of the cuttings was modest, averaging $1.1 \mathrm{~m}^{3} / \mathrm{ha}$ in the $1820 \mathrm{~s}$. This indicates that clear cutting was not applied consistently, at least initially. Thus, due to lack of demand part of the mature spruces were left standing, since the local demand was mainly for firewood. Owing to the cutting prohibitions dating from the 17th century, felling of broadleaf trees on an extensive scale was also avoided. In quite a number of years the permitted quota of timber was not logged; in some places, this essentially meant area-by-area selection felling. Felling intensity increased over the years, however, reaching approximately $2.6 \mathrm{~m}^{3} / \mathrm{ha}$ by the mid-19th century and even upwards of $3 \mathrm{~m}^{3} / \mathrm{ha}$ by the early 20 th century, which signalled the use of clear cutting.

All the written sources dating from the 19th century underline good and rapid natural regeneration of clearcut areas with the spruce and deciduous species on Abruka, therefore no forest plantations were planned here. In the final analysis, the clearcut spruce areas left for natural regeneration were inevitably to grow over with deciduous trees under Abruka's circumstances, primarily with the birch. 


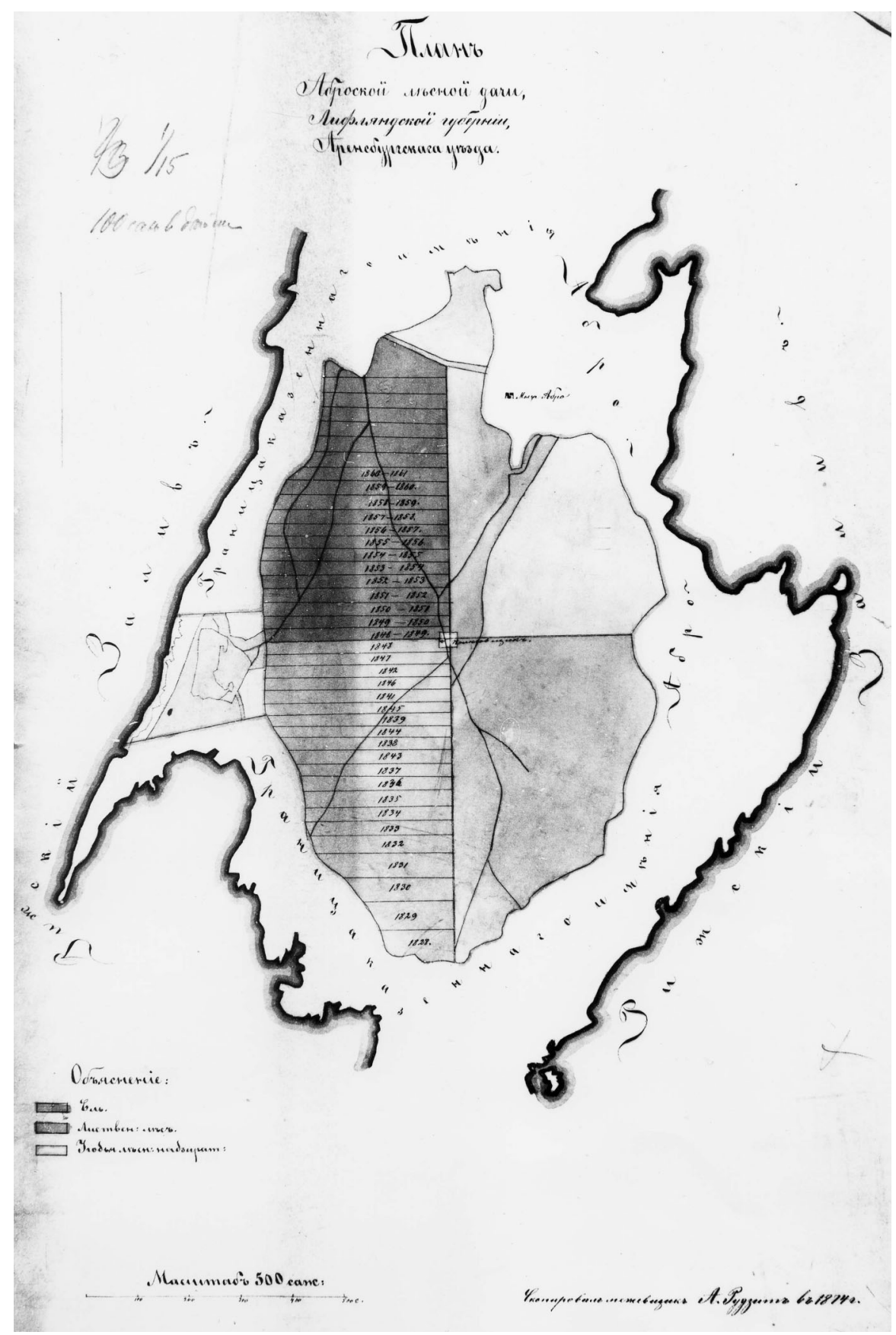

Fig. 1. Clear cutting on Abruka (1828-1861) (Estonian Historical Archives: 3724, 4, 997). The border between forest and agricultural land is shown with a dark narrow continuous line. In 1827 logging was started in the western side by 4.1-ha areas. By the late 1860s cuttings had been performed throughout the island's western forest where one-year felling areas bordering on one another can be seen on the forest map as regular stripes oriented from west to east and marked with the year of cutting. 
Maintenance felling, which might have stopped the process, was not performed on the island. Intensive pasturing in the forest may also have played a role in the failure of conifer regeneration.

In 1898 the Abruka forest was designated to the deciduous tree management system with a 60 -year rotation. It was recognized that clear cuttings had caused an alteration of the dominant tree species of the so far spruce-dominated forest. Felling of better stands had been particularly intensive in the last decades. It was stated that the dominant tree species of the 115-ha spruce forest area had regenerated well after felling yet was ultimately suppressed by deciduous trees. It was found that for that reason it was unreasonable to spend time and money on preserving the spruce stands. If possible, however, maintenance felling needed to be carried out to create more favourable conditions for spruce growth. Thenceforward, the focus was to be shifted on the production of firewood. The size of the one-year felling area was to be 4.9 ha. Cuttings were planned in the northeastern part of the island, the site of the oldest, including mature, spruce stands (shown with dark grey in Fig. 2). Forest was to be utilized by clear cuttings on areas of up to $106 \mathrm{~m}$ in width. The every-other-area logging system at a 5-year interval was to be used. This method, rare in deciduous tree management, was due to a desire to promote the spruce's potential for natural regeneration. If necessary, felling of over-mature and dead trees was envisaged throughout the forest, as was removal of wind-fallen trees. Apart from final felling and sanitary felling, maintenance felling on 148 ha was planned for the next ten years, intended for cutting out less valuable tree species (willows, hazels) and contributing, first and foremost, to spruce growth. The density of middle-aged and older stands was typically $0.7-0.8$, whereas the natural young stands sprouting on former clearcut areas were considered very dense. Forest plantations were deemed unnecessary. However, it was recommended to clean the existing sparse stands and clearings (23.4 ha) of hazel coppice and to seed them with oak.

\section{Abruka forest as a hardwood production forest (1900s-1920s)}

The forest management plan approved in 1900 treated the Abruka forest as a traditional production forest to which a deciduous forest management scheme with a short cutting cycle should be applied. Clear cutting and intensive maintenance of forests posed a severe threat to the forest community that was already greatly influenced by human activity. On the initiative of the local district forester attempts were made to decrease the pressure on the forest (until 1916, barely $71 \%$ of the yield prescribed in the forest management plan was logged), yet the average felling intensity turned out to be approximately $3.5 \mathrm{~m}^{3} / \mathrm{ha}$ while the respective figure for the Kuressaare forest district was $2.1 \mathrm{~m}^{3} / \mathrm{ha}$. There are no reports of maintenance felling on a more extensive scale. In the early 20th century the first forest sowing attempts were made on Abruka on a total of 13.4 ha, 


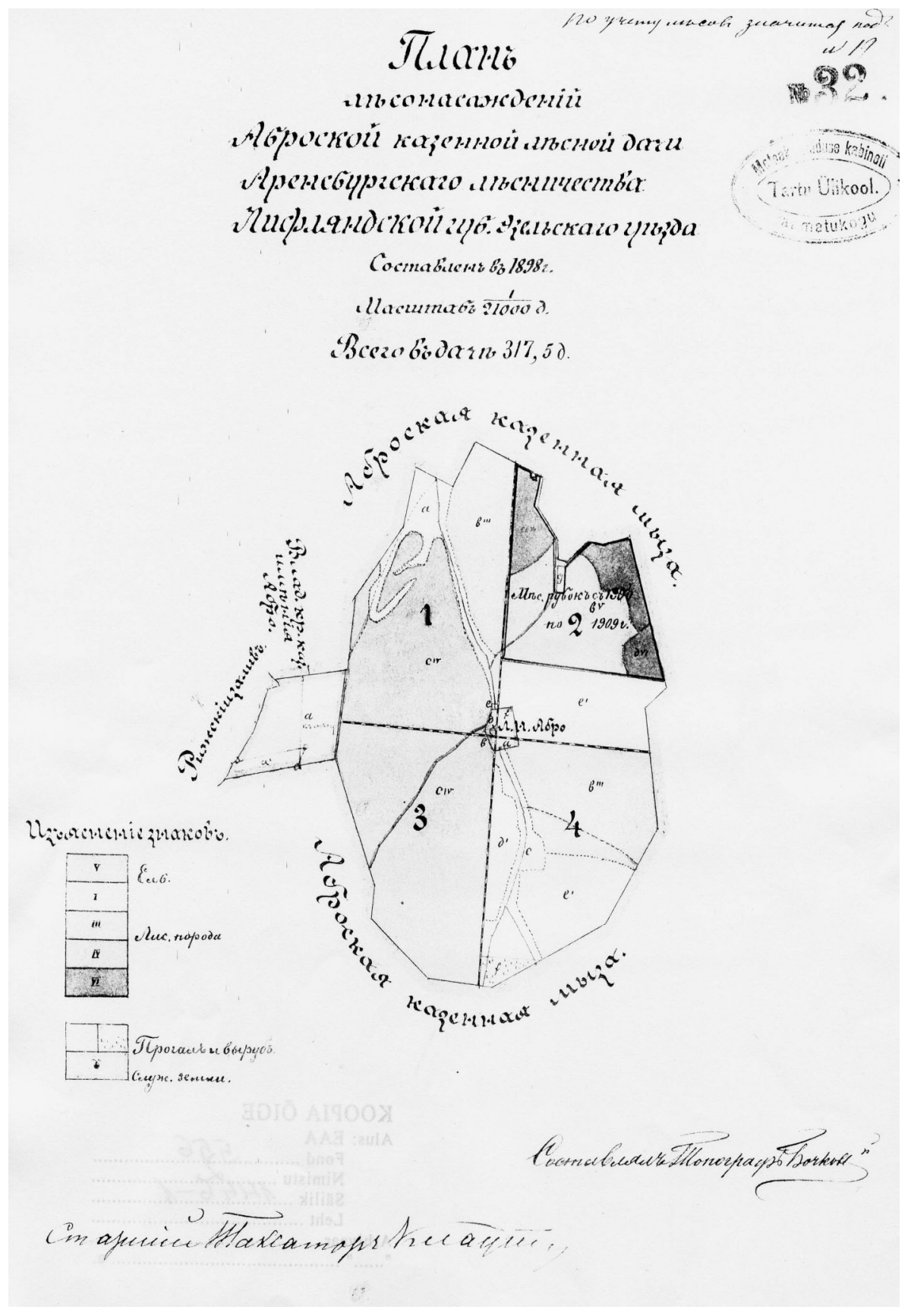

Fig. 2. Abruka forest in 1898 (Estonian Historical Archives: 566, 2, 230). Forests were divided into four comparments (Nos. 1-4). Cuttings were planned in compartment 2, northeastern part of the island, the site of the oldest spruce stands (shown with dark grey). The forest was to be utilized by clear cuttings of irregular shape, but not more than $106 \mathrm{~m}$ in width. The every-other-area logging system with a 5-year interval was to be used. 
unfortunately using pine seed, a crop unsuitable for the local soils. There are no reports of any large-scale establishment of oak plantations either. At that time oaks were growing as single giants on hayfields and pasturelands.

The situation became worse during and following World War I, as evidenced by a substantial increase in clearcut areas. In 1920 Abruka had 55 ha of clearcut areas, open spaces, and clearings, accounting for $16 \%$ of the forest land. By 1924 they had been supplemented with a further 28 ha of clearcut areas. In the early 1920s maintenance felling was launched while no forest plantations were established.

Under the 1924 forest management plan, Abruka was to remain a production forest to be treated as a deciduous forest subjected to a 70-year cutting cycle. The management plan envisaged a total of 22 ha of clear cutting in the southwestern part of the island for the next 10 years. In actual fact, 20 ha was cut in the second half of the 1920s alone (Fig. 3). Clearcut areas can be seen on the forest map as regular sections mostly in the southern part of compartment 28. Maintenance felling was planned on 42 ha for the management period and forest plantations were not considered necessary.

\section{Abruka forest as a protected forest (since the 1930s)}

In the early 1930s clear cutting was discarded. In 1937 the most nemoral-like forest compartment ( $98 \mathrm{ha}$ ) in the northwestern part of the island was subjected to wildlife conservation, which barred traditional forest management activity and grazing of livestock there. Necessary sanitary felling was permitted. The initial plan of subjecting the whole forest on the island to wildlife conservation was rejected since that could have affected the economic interests of the local population. Clear cuttings remained banned.

The Abruka forest suffered no harm during World War II, and it was also left out of the extensive post-war cutting schemes. As it was ranked among the socalled 1st-class forests, clear cutting was ruled out. Forest use was limited here to modest cuttings (mostly maintenance cuttings and sanitary cuttings) performed in protected forests. In 1957 the former wildlife conservation compartment was turned into a national botanical-zoological reserve called Abruka Island Nemoral Forest with an area of approximately $91 \mathrm{ha}$, intended to guarantee the preservation of the species-rich nemoral forest along with its ground vegetation as well as the fauna. Direct human activity was banned on the reserve whereas the rest of the island's forest was managed as a surface protection forest where modest maintenance felling and, if necessary, sanitary felling was allowed. The clearings, which in fact had largely grown over with forest already, were left to natural regeneration, with the exception of a 0.8 -ha ash and maple plantation, which was established there in 1963. Subsequently, the only period of considerable logging has been the clearing of the 1969 storm damage in 1969-1986, when the felling volume was at least $4000 \mathrm{~m}^{3}$. 


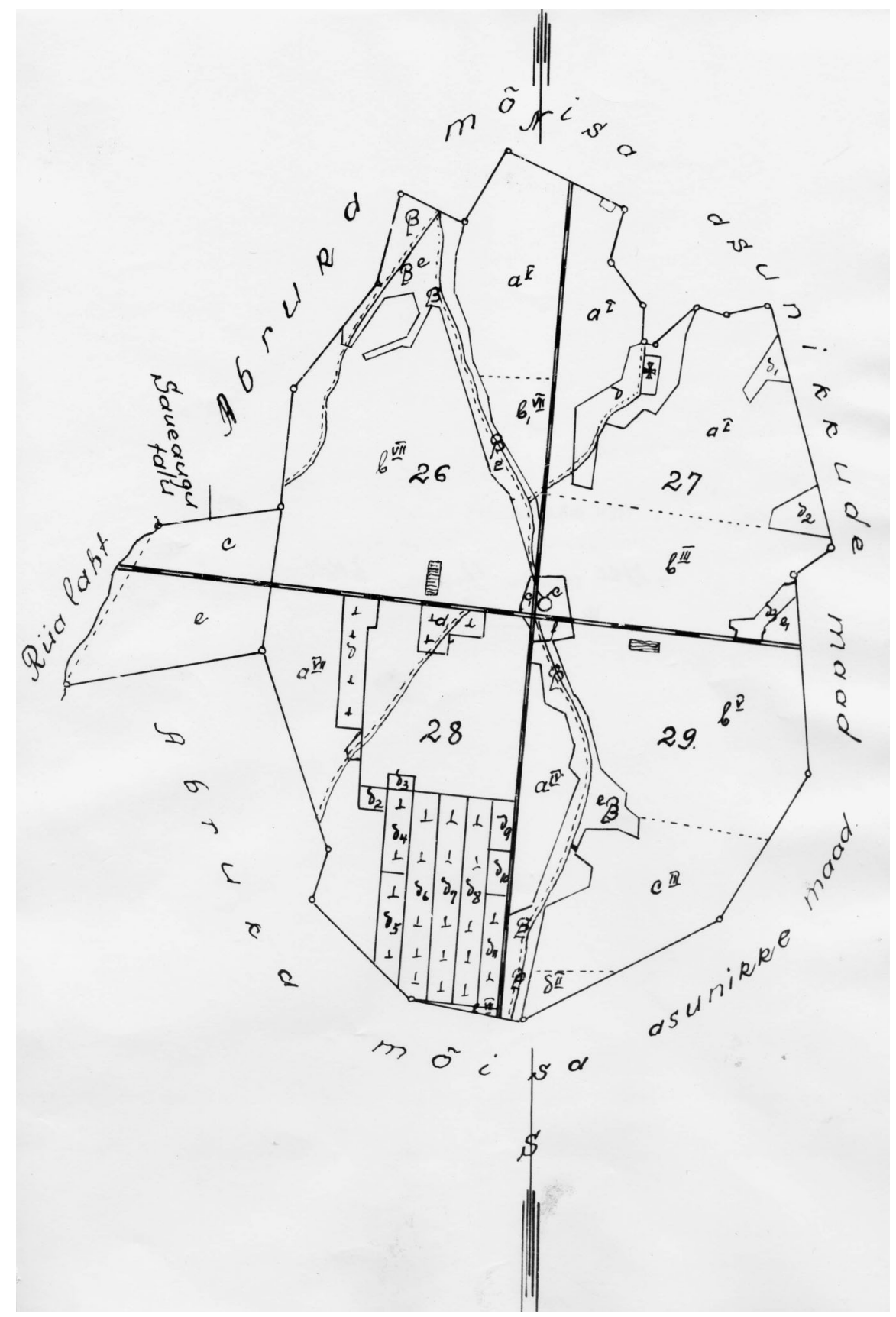

Fig. 3. Abruka forest in the early 1930s (Estonian Historical Archives: 2100, 12, 616). Forests were divided into four compartments (Nos. 26-29) surrounded mostly by rented agricultural lands. In the second half of the 1920s, 20 ha of mature spruce dominated forest was clearcut. Clearcut areas can be seen in the figure as regular sections mostly in the southern part of compartment 28 , less in the northern part. 


\section{CONCLUSIONS AND SUMMARY}

The forests on Abruka Island are healthy, rich-in-species, and lush nemoral forests hosting several endangered and vulnerable species. The formation of the forest community of today's Abruka Island has in the last couple of centuries been decisively impacted by human activity. The local broadleaf species can clearly be regarded as ancient relicts whose survival has been facilitated by the mild maritime climate. In a later period, however, the spruce started to spread, rising to the rank of the island's dominant species until the onset of active human involvement. Spruce-dominated stands were prevalent on the island at least until the 1860s. The 1898 forest survey registered a change in the dominant tree species - that year birch stands constituted $84 \%$ of the total area of the island's forests. That development was due to clear cuttings, which were widespread early that century and grew particularly intensive in its final decades.

The current hardwood nemoral stands and, in particular, wide spread of birch forests must be regarded as the very result of man's forest management activity. The influence and orientation of the activity may be divided into the following distinct stages:

(1) The period until the 19th century, which was characterized by modest human intervention through modest selection felling;

(2) The early 19th century until the early 1930s, when Abruka was initially regarded as a conifer production forest. Transition to clear cutting under no forest management works (forest plantation, maintenance felling) set the stage for the triumph of pioneer species (birch, aspen), which since the early 20th century was further facilitated by the application of a hardwood management scheme with a short cutting cycle. At the same time, it fostered the development of the nemoral forest community in some places;

(3) Beginning from the 1930s the island's forests have been subjected to a stricter or looser protection regime, which on the one hand has contributed to a rise in the island's species richness but on the other has created conditions for the restoration of the dominance of the spruce as the tree species well suited to the island's soil conditions.

The rapid change in the island's stands over less than 70 years from the introduction of clear cutting vividly demonstrates how man's active intervention in forest development leads to alterations in tree species and the formation of uncommon plant communities. Over the last 50 years, the forests of Abruka have remained relatively unvaried precisely because of the lack of human influence. Under no human interference, the process of tree species alteration slows down yet still continues towards the spread of the species suited to and more competitive on the site. If we desire to preserve the current species richness and environment of Abruka forests we need to be careful in our planning of future human activity.

\section{ACKNOWLEDGEMENT}

The study was financed by the Estonian Science Foundation grant 4130. 


\section{REFERENCES}

Eichwald, K. 1934. Saaremaa taimkate. In Eesti. Maateaduslik, majanduslik ja ajalooline kirjeldus. VI. Saaremaa, pp. 40-74. Tartu.

Jõgiste, K., Kuuba, R., Viilma, K., Korjus, H., Kiviste, A., Kalda, A., Parmasto, E., Jüriado, I., Lõhmus, P., Õunap, H., Öövel, J. \& Amos, T. 2002. Metsade looduslikkuse taastamise juhend. http://www.metsahoiu.ee

Kalda, A. 1979. Abruka saare mets. Eesti Loodus, 11, 734-739.

Laasimer, L. 1958. Abruka saare metsas. Noorus, 9, 20-21.

Laasimer, L. 1965. Eesti NSV taimkate. Eesti NSV Teaduste Akadeemia Zooloogia ja Botaanika Instituut, Tallinn.

Lippmaa, T. 1935. Une analyse des forêts de 1'île Estonienne d’Abruka (Abro) sur la base des associations unistrates. Acta Comment. Univ. Tartu. (Dorpat.), A, XXVIII, 1, 1-97.

Lippmaa, T. 1937. Abruka saare mets. In Looduskaitse I, pp. 71-77. Tallinn.

Lippmaa, T. 1939. Abruka metsa ökoloogiast. In Eesti metsanduse aastaraamat IX, pp. 194-196. Tartu.

Lippmaa, T. 1940. Contribution to the ecology of the Estonian deciduous forest. In Eesti Teaduste Akadeemia aastaraamat. Annales Academiae Scientiarum Estonicae 1, pp. 31-86. Tallinn.

Meikar, T. 1992. Abruka saare mets. Akadeemia, 4, 12, 2600-2612.

Meikar, T., Lepp, A. \& Viilma, K. 1999. Abruka metsakooslus - looduse ja inimtegevuse koosmõju tulem. In Metsanduslikud uurimused XXXI. Forestry Studies XXXI, pp. 36-51. Forest Research Institute of EAU, Tartu.

Sass, A. 1867. Bericht über die bis zur 17. Märtz 1866 angestellten auf den Oesel'schen Kreis bezüglichen naturwissenschaftlichen Untersuchungen. In Bericht des Vereins zur Kunde Oesel's in Arensburg, 1, pp. 1-16.

Schmidt, F. 1855. Flora des silurischen Bodens von Ehstland, Nord-Livland und Oesel. Dorpat.

Voolma, K. 1998. Ülevaade metsaentomoloogia ajaloost Eestis. In Teaduse ajaloo lehekülgi Eestis. XII kogumik. Metsateaduse ajaloost Eestis, pp. 140-158. Tallinn.

\section{Inimtekkeliste häiringute mõju Abruka saare metsakoosluste arengudünaamikas}

\section{Toivo Meikar, Kaili Viilma ja Alar Lepp}

Tänapäeval kasvab Abruka saarel liigirikas ja lopsakas salumets, mida on käsitletud kui tänu siinsele pehmele merelisele kliimale säilinud relikti Eestis kunagi laialt levinud laialehistest metsadest. Samas on Abrukat 19. sajandi keskpaigani kirjalikes allikates kuusikuna käsitletud. 1898. aasta metsakorralduse andmeil moodustasid kasepuistud saare metsade pindalast juba $84 \%$. Metsakorraldusmaterjalide ja muu dokumentatsiooni analüïs näitab, et saare metsakoosluse kujundamisel on viimasel paarisajal aastal olnud määravaks inimfaktor - 19. sajandi algusest kasutatud lageraie, samas aga metsakultuuride ja hooldusraiete puudumine. 1930. aastaiks, mil saarel võeti kasutusele kaitserežiim, oli kuusepuistute osa langenud 0,1\%-ni, puistute koosseisus oli kuuse osakaaluks $8,4 \%$. Kaitserežiimi rakendumisega on suurenenud metsa liigiline mitmekesisus, samas on loodud perspektiivis võimalused kuuse kui saare pinnaseoludele sobiva puuliigi osakaalu suurendamiseks. 